Article

\title{
The Role of Regional Determinants in the Deployment of Renewable Energy in Farms. The Case of Spain
}

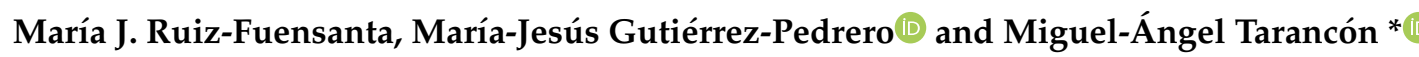 \\ Seminar on Sustainable Economy, Faculty of Law and Social Sciences, University of Castilla-La Mancha, \\ Ronda de Toledo s/n, 13071 Ciudad Real, Spain; mariajesus.ruiz@uclm.es (M.J.R.-F.); \\ mariajesus.gutierrez@uclm.es (M.-J.G.-P.) \\ * Correspondence: miguelangel.tarancon@uclm.es
}

Received: 29 August 2019; Accepted: 24 October 2019; Published: 25 October 2019

check for updates

\begin{abstract}
We provide a multilevel logit model based on panel data which allows a capturing of the determinants of investment in their capacity for generating renewable energy in farms. As a novelty, we focus on regional determinants in order to assess the role of the regional dimension in making decisions by farmers about whether or not to invest in renewable energy generation. The relevance of this territorial/regional dimension acquires even greater significance in countries with a high degree of administrative decentralization, as is the case in Spain; where energy legislation gives a central role to regional governments in aspects related to the promotion of renewable energy sources. Multilevel analysis allows us to evaluate together both dimensions: Individual and regional. The results highlight the importance of the $\mathrm{R} \& \mathrm{D}$ investment carried out in regions, as well as the fact that there is an environment that favors the diffusion of renewable energies into the territory. Other variables, such as the level of agricultural income or regional energy intensity, do not seem to have significant relevance in the light of these results.
\end{abstract}

Keywords: renewable energy; farms; regional; multilevel analysis; panel data; European Union; Spain

\section{Introduction}

The XXI United Nations Conference on Climate Change (COP21) held in Paris in 2015 expressed the need to step up efforts to mitigate the effects of global warming, setting the goal of preventing the earth's surface temperature from rising more than 1.5 degrees Celsius with respect to pre-industrial levels [1]. Based on this specific objective, the various supranational states and entities have established their particular strategies to contribute to achieving this. In the case of the European Union (EU), the objectives for 2030 have been set to reduce greenhouse gas (GHG) emissions by at least $40 \%$, reducing the share of renewable energy by at least $32 \%$ of the energy mix, and improving energy efficiency by at least $32.5 \%$. By 2050, the aim is to achieve a neutral economy in terms of GHG emissions, which includes the complete decarbonization of the energy supply, and the creation of carbon sinks through the development of agriculture and more sustainable land use.

In this strategic framework, the Farm Sector plays an important role in several ways. Firstly, this sector is an emitter of pollutants that contribute to the global warming process. Secondly, the activity carried out by certain farms may imply an opportunity cost, as they are not aimed at obtaining environmentally sustainable production or crops or forest mass that act as carbon sinks. Finally, farms can contribute significantly to achieving energy objectives, both by improving energy efficiency in their activity, and by incorporating renewable energy generation into their operations.

In this regard, based on the estimates offered by some works, such as that by Pedroli \& Langeveld [2], prepared within the framework of the European project "Impacts of Renewable Energy on European 
Farmers", the estimated contribution of farms in the production of renewable energy could amount to $25 \%$ of total renewable energy generated.

Another noteworthy fact is that more than three quarters of the energy consumed in agriculture comes from fossil fuels, a percentage only surpassed by the Transport sector. That is why the agricultural sector plays an important role in the European transition strategy towards an energy system based upon renewable energy. This circumstance is evident in the incentives to diversify farm activity through the production of this type of energy [3-5]. For example, the Renewable Energy Plan for Spain 2011-2020 includes various proposals to encourage the use of renewable energies in agricultural holdings, such as photovoltaic, low power wind energy, or geothermal energy for application in greenhouses and the heating of floors. Moreover, in the National Integrated Energy and Climate Plan [6], it is expected that the presence of renewable energy in the agricultural sector will increase from 94 to 278 kilotonnes of oil equivalent (ktep) over the period 2021-2030.

There are four main types of sources established in the agricultural sector: Bio, solar, wind and geothermal energy [7]. It is not easy to make a detailed estimate of the mix of renewable energy production specific to the agricultural sector. In this regard, Pedroli \& Langeveld [2] estimate energy production from farms in the EU in 2008, for two alternative scenarios in 2020: One consistent with the national renewable energy plans (NREAPs), and another in which the scenario is modified, based on the NREAPs to take into account additional stimulus measures for the deployment of renewable energies designed from the specific characteristics of the farms in each country (NREAPs + ). The structures derived from the three cases are shown in Table 1:

Table 1. Renewable energy production in farms. Estimation in EU 2008/2020.

\begin{tabular}{ccccccc}
\hline \multirow{2}{*}{ Energy Source } & \multicolumn{2}{c}{$\mathbf{2 0 0 8}$} & \multicolumn{2}{c}{ 2020 NREAP } & \multicolumn{2}{c}{ 2020 NREAP + } \\
\cline { 2 - 7 } & Ktoe & \% & Ktoe & $\%$ & Ktoe & $\%$ \\
\hline Wind & 7288.3 & 19.61 & $32,692.7$ & 34.27 & 53,797 & 36.98 \\
Solar & 34.4 & 0.09 & 957.8 & 1.00 & 1297.7 & 0.89 \\
Bioenergy (except f. wood) & $24,620.7$ & 66.26 & $61,497.6$ & 64.46 & $90,058.9$ & 61.90 \\
Forest wood & 5158 & 13.88 & 0.0 & 0.00 & 0.0 & 0.00 \\
Geothermal & 36.7 & 0.10 & 224.4 & 0.24 & 276.3 & 0.19 \\
Others & 21.6 & 0.06 & 33.6 & 0.04 & 53.9 & 0.04 \\
Total & $37,159.7$ & 100.00 & $95,406.1$ & 100.00 & $145,483.8$ & 100.00 \\
\hline
\end{tabular}

Note: The 2020 national renewable energy plan (NREAP) scenario exclusively considers the NREAPs of the different member states. The 2020 NREAP + scenario modifies the previous scenario, taking into account additional stimulus measures for the deployment of renewable energy in farms. Source: Our own elaboration based on Pedroli \& Langeveld [2].

As can be seen in the table above, bioenergy production accounted for around $2 / 3$ of total renewable energy production in 2008; the goal set for 2020 falling slightly. Also, wind energy accounted for around $20 \%$ of total renewable energy and bioenergy produced by European farms in 2008, a proportion that increased to a value between 34\% (NREAP scenario) and 37\% (NREAP + scenario). Solar energy, meanwhile, increased its weight in the mix from just a testimonial amount to about $1 \%$. Finally, geothermal energy rose from a $0.1 \%$ share in the mix of renewable energy generation in farms to approximately $0.2 \%$.

There are previous works that have proven that the degree of involvement of farms in the generation of renewable energy, in their different types, depends upon a series of determining factors related to farm characteristics, such as size and legal status, personal characteristics of the person in charge of the holding, or its business characteristics [8,9]. However, the incidence of certain determinants at a regional level has not obtained the same attention in literature, despite its relevance [10]. This relevance acquires even greater significance in countries with a high degree of administrative decentralization, as is the case in Spain, where energy legislation itself gives a central role to regional governments in aspects related to the promotion of renewable energy sources. 
Thus, for example, Law 54/97 on the Electricity Sector stated, that regardless of the competences attributed to the General State Administration, Autonomous Communities are responsible for "the promotion of special regime renewable energy and energy efficiency in their Community territory" [11]. More recently, a Draft of the Integrated National Energy and Climate Plan of Spain explicitly mentions the primary role of regional administrations in the process of energy transition towards a sustainable model [6]. This article aims to help reduce this gap by analyzing the role that these determinants of regional dimension play on the probability of farms investing in renewable energy generation in Spain. Among the regional factors assessed are the energy dependence of the sector in each region, as well as the investment made in research and regional development.

Furthermore, another of the main contributions of this work, apart from highlighting the territorial dimension of the question being studied, is that, unlike other studies whose analysis is limited to geographical areas and/or specific agricultural activities, here a very large and representative sample of the total number of farms located in Spain is used, from the Survey on the structure of farms in 2016 (SSF-2016) prepared by the National Institute of Statistics (INE).

The article is structured as follows. The next section includes a review of the literature that highlights the main determinants for the deployment of renewable energy sources in farms, paying special attention to regional determinants that will later be taken into account in the empirical analysis. Then, we present the statistical information used in the study and describe the multilevel logit model used in the estimation. The third section shows the main results obtained. We discuss the findings in the fourth section. Finally, a firth section includes the main conclusions of the study and establishes a series of political implications.

\section{Materials and Methods}

\subsection{Literature Review}

There is not an excessive number of contributions in the literature that systematically identify the determinants that influence the adoption of renewable energy production systems by farms. In addition, there is a certain level of heterogeneity, both from the point of view of the scope (geographic area, sample used), and the technique used by the farm for the sample information. Finally, there is also some disparity in the renewable energy source under study, mainly distinguishing contributions that analyze bioenergy production, and those that analyze the incorporation of solar PV and/or wind energy infrastructures; although some contributions have also been published that analyze the incorporation of renewable energy production in general into farm activity. Among the contributions that identify the various determinants of farm investment in renewable energy production, those listed in Table 2 stand out.

Table 2. Determinants for the deployment of renewable energy in farms.

\begin{tabular}{|c|c|c|c|c|}
\hline Contribution & Scope & $\begin{array}{c}\text { Type of Renewable } \\
\text { Energy }\end{array}$ & Type of Analysis & Main Determinants \\
\hline Jensen et al. [12] & $\begin{array}{l}3499 \text { farmers. } \\
\text { Tennessee, US, } \\
2005 .\end{array}$ & $\begin{array}{l}\text { Bioenergy } \\
\text { (switchgrass) }\end{array}$ & $\begin{array}{c}\text { Tobit econometric } \\
\text { model }\end{array}$ & $\begin{array}{l}\text { Cultivated area, land } \\
\text { ownership, no-till, livestock, } \\
\text { soya crop, age, education } \\
\text { level, degree of development } \\
\text { of the market, desire to } \\
\text { increase autochthonous wild } \\
\text { species on the plantation, } \\
\text { income stability, net income } \\
\text { per hectare, need for } \\
\text { technical assistance, conflict } \\
\text { over the growing period } \\
\text { with other crops. }\end{array}$ \\
\hline
\end{tabular}


Table 2. Cont.

\begin{tabular}{|c|c|c|c|c|}
\hline Contribution & Scope & $\begin{array}{l}\text { Type of Renewable } \\
\text { Energy }\end{array}$ & Type of Analysis & Main Determinants \\
\hline Adams et al. [13] & $\begin{array}{l}\text { United } \\
\text { Kingdom. }\end{array}$ & Bioenergy & $\begin{array}{c}\text { Qualitative } \\
\text { analysis based on } \\
\text { interviews }\end{array}$ & $\begin{array}{l}\text { Competition vs. other } \\
\text { investments, return on } \\
\text { investment, funding } \\
\text { uncertainty, land availability, } \\
\text { profitable investment, } \\
\text { reduce dependence on fossil } \\
\text { fuels, carbon reduction, } \\
\text { growing market. }\end{array}$ \\
\hline Tranter et al. [14] & $\begin{array}{l}384 \text { farmers. } \\
\text { United } \\
\text { Kingdom, } \\
\text { 2008-2009. }\end{array}$ & Bioenergy (biogas) & $\begin{array}{l}\text { Testing statistical } \\
\text { significance on } \\
\text { differences } \\
\text { between observed } \\
\text { groups }\end{array}$ & $\begin{array}{l}\text { Cultivated area, land } \\
\text { ownership, livestock, } \\
\text { number of full time workers, } \\
\text { age at which full time } \\
\text { studies are abandoned, } \\
\text { income from sources other } \\
\text { than farms, expectations of } \\
\text { profit, costs of introducing } \\
\text { technology. }\end{array}$ \\
\hline $\begin{array}{l}\text { Bartollini and } \\
\text { Viaggi [3] }\end{array}$ & $\begin{array}{l}300 \text { farmers. } \\
\text { Bologna, Italy, } \\
2009 .\end{array}$ & $\begin{array}{l}\text { Bioenergy (biogas, } \\
\text { energy crops) }\end{array}$ & $\begin{array}{l}\text { Mathematical } \\
\text { programming } \\
\text { model }\end{array}$ & $\begin{array}{l}\text { Size of the farm, percentage } \\
\text { of full time workers, } \\
\text { payments to the farm from } \\
\text { the Common Agricultural } \\
\text { Policy, livestock. }\end{array}$ \\
\hline Huttunen [15] & $\begin{array}{l}15 \text { farmers. } \\
\text { Central Finland, } \\
\text { 2006-2007. }\end{array}$ & Bioenergy (heat plants) & $\begin{array}{c}\text { Qualitative } \\
\text { analysis based on } \\
\text { interviews }\end{array}$ & $\begin{array}{c}\text { Type of farm (legal status: } \\
\text { individual, cooperative ... ), } \\
\text { size of farm, expected } \\
\text { income, qualifications, } \\
\text { environmental aspects, } \\
\text { effects on the community. }\end{array}$ \\
\hline Reise et al. [16] & $\begin{array}{l}135 \text { farmers. } \\
\text { Northwest } \\
\text { Germany, } 2009 .\end{array}$ & Bioenergy (biogas) & Linear Regression & $\begin{array}{l}\text { Cost of capital, risk, soil } \\
\text { fertility, environmental } \\
\text { aspects, subsidies, } \\
\text { experience. }\end{array}$ \\
\hline Tate et al. [17] & $\begin{array}{l}2000 \text { farmers. } \\
\text { West Midlands, } \\
\text { United } \\
\text { Kingdom } 2011 .\end{array}$ & $\begin{array}{l}\text { Bioenergy, } \mathrm{PV}, \mathrm{CHP} \\
\text { wind power }\end{array}$ & $\begin{array}{l}\text { Principal } \\
\text { Component } \\
\text { Analysis }\end{array}$ & $\begin{array}{l}\text { Education, age, land } \\
\text { ownership, local councils } \\
\text { provide support to farmers } \\
\text { to set up RE on farms, } \\
\text { finding suitable renewable } \\
\text { technology, expectations of } \\
\text { financial feasibility, } \\
\text { expectations of greater } \\
\text { profits than other alternative } \\
\text { agricultural businesses, size } \\
\text { of the farm, agricultural } \\
\text { income, }\end{array}$ \\
\hline $\begin{array}{c}\text { Beckman and } \\
\text { Xiarchos [8] }\end{array}$ & $\begin{array}{l}8569 \text { farmers. } \\
\text { California, } 2007\end{array}$ & PV, wind power & $\begin{array}{l}\text { Heteroskedastic } \\
\text { ordered binary } \\
\text { model }\end{array}$ & $\begin{array}{l}\text { Internet connection, } \\
\text { education, age, land } \\
\text { ownership, income, } \\
\text { experience as a farmer, } \\
\text { presence of farm manager, } \\
\text { type of crop, organic } \\
\text { agriculture, livestock, size of } \\
\text { the farm, profitability, } \\
\text { number of workers, capital, } \\
\text { prices of inputs, price of } \\
\text { electricity, regional policies } \\
\text { (funding). }\end{array}$ \\
\hline
\end{tabular}


Table 2. Cont.

\begin{tabular}{|c|c|c|c|c|}
\hline Contribution & Scope & $\begin{array}{l}\text { Type of Renewable } \\
\text { Energy }\end{array}$ & Type of Analysis & Main Determinants \\
\hline $\begin{array}{c}\text { Brudermann et al. } \\
\text { [18] }\end{array}$ & $\begin{array}{l}196 \text { farmers. } \\
\text { Austria, } \\
\text { 2011-2012 }\end{array}$ & PV & $\begin{array}{l}\text { Testing statistical } \\
\text { significance on } \\
\text { differences } \\
\text { between observed } \\
\text { groups }\end{array}$ & $\begin{array}{c}\text { Responsivity for future } \\
\text { generations, period to pay } \\
\text { back infrastructure, } \\
\text { generation of electricity } \\
\text { following repayment, lower } \\
\text { cost of electrical energy, } \\
\text { investment safety, full time } \\
\text { dedication, }\end{array}$ \\
\hline Borchers et al. [19] & $\begin{array}{l}8569 \text { farms. } \\
\text { United States, } \\
\text { 2007-2009 }\end{array}$ & PV, wind power & $\begin{array}{l}\text { Multilevel logit } \\
\text { model }\end{array}$ & $\begin{array}{l}\text { Size of the farm, total value } \\
\text { of production, organic } \\
\text { agriculture, type of crop, } \\
\text { livestock, number of } \\
\text { workers, number of days } \\
\text { dedicated to working } \\
\text { outside the farm, farm } \\
\text { house, full time dedication, } \\
\text { Internet connection, } \\
\text { experience as a farmer, } \\
\text { income, solar potential, } \\
\text { good Net Metering practices } \\
\text { and interconnections, } \\
\text { incentives for the } \\
\text { production, percentage of } \\
\text { clients attended by energy } \\
\text { cooperatives, regional per } \\
\text { capita income. }\end{array}$ \\
\hline $\begin{array}{l}\text { Sutherland and } \\
\text { Holstead [20] }\end{array}$ & $\begin{array}{c}23 \text { farmers. } \\
\text { North East } \\
\text { Scotland, } 2012\end{array}$ & Wind power & $\begin{array}{l}\text { Qualitative } \\
\text { analysis based on } \\
\text { interviews }\end{array}$ & $\begin{array}{l}\text { Business diversification, } \\
\text { increase income, reduce risk, } \\
\text { respond to market } \\
\text { opportunities, exploit farm } \\
\text { resources, explore personal } \\
\text { interests and employ } \\
\text { additional family members. }\end{array}$ \\
\hline $\begin{array}{l}\text { Schafffer and } \\
\text { Düvelmeyer [10] }\end{array}$ & $\begin{array}{l}71 \text { rural } \\
\text { counties. } \\
\text { Bavaria, } \\
2004 / 2012\end{array}$ & $\begin{array}{l}\text { Bioenergy (biogas), PV, } \\
\text { wind power }\end{array}$ & $\begin{array}{l}\text { Spatial regression } \\
\text { analysis }\end{array}$ & $\begin{array}{l}\text { Time lag take off, size of } \\
\text { farms, share of land farmed } \\
\text { on a regular basis, share of } \\
\text { organic food. }\end{array}$ \\
\hline $\begin{array}{l}\text { Sutherland et al. } \\
\text { [21] }\end{array}$ & $\begin{array}{c}2416 \\
\text { agricultural } \\
\text { holdings. } \\
\text { Scotland, } 2013\end{array}$ & $\begin{array}{l}\text { Renewable energy in } \\
\text { general }\end{array}$ & $\begin{array}{l}\text { Structural equation } \\
\text { model }\end{array}$ & $\begin{array}{l}\text { Age, education, experience, } \\
\text { plans to continue with the } \\
\text { farm, successor identified, } \\
\text { access to information, } \\
\text { ownership of the farm, area, } \\
\text { number of workers, organic } \\
\text { certification, income from } \\
\text { outside the farm, subsidies, } \\
\text { non-farm investment, sole } \\
\text { payments by the CAP. }\end{array}$ \\
\hline Ge et al. [9] & $\begin{array}{l}20946 \text { farms. } \\
\text { Scotland, } 2011\end{array}$ & $\begin{array}{l}\text { Bioenergy (biomass), } \\
\text { PV, wind power }\end{array}$ & Logit model & $\begin{array}{l}\text { Type of crop, type of } \\
\text { livestock, mixed agricultural } \\
\text { land, geographic factors, } \\
\text { weather and climate factors, } \\
\text { tourism, farm products } \\
\text { processing, wood } \\
\text { processing, percentage de } \\
\text { area owned, age of the } \\
\text { farmer, exclusive dedication, } \\
\text { production earmarked for } \\
\text { self-consumption, existence } \\
\text { of a different manager to the } \\
\text { owner. }\end{array}$ \\
\hline
\end{tabular}


Starting with the schemes proposed by Beckman and Xiarchos [8] and Ge et al. [9], the determinants identified in the previous contributions can be classified into factors linked to the person in charge of the farm, the factors of the farm and socio-economic factors.

Regarding the factors linked to the person responsible for the farm, it can be concluded in general, based on the contributions analyzed, that there are two main determinants that affect the propensity to invest in renewable energy sources, these being the age of the person responsible and his or her training. In the first case, the contributions studied confirm an inverse relationship between the age of the person in charge of the farm and their proactivity towards investment in renewables $[8,12,14,17,19-21]$. On the contrary, training seems to be a decisive driver for farm investment in renewable technology $[12,14,17,21]$.

With regard to the farm characteristics, several determinants are taken into account in literature. First of all, the type of farm seems to have some influence on the decision to invest in renewable energy sources, so that property holdings tend to invest more in energy production $[8,14]$, which is probably motivated by the high investment required in infrastructure [21]. The relationship between the orientation of the farm towards obtaining economic profits and the investment in renewable energy sources $[14,18,21,22]$ has also been considered. Thus, in some empirical works the fact that the person in charge of the farm knows the economic benefit that he or she will obtain with the investment, is identified as an incentive [20]; while other types of motivations, such as environmental motivations, seem to have less impact on the decision to invest in renewable energy production, as is the case with certain biomass producing farms in Finland [15], and some Scottish [20] or German farms [16]. Another determinant related to the farm characteristics refers to whether the person in charge resides or not on the farm itself, residence being a driver which favors investment $[8,19]$.

In addition, the size of the farm, together with the objective of production diversification, are factors that also favor investment in renewable energy sources [3,10,14,18,19,21]. And finally, the type of crop or agricultural activity also has an influence on the propensity to invest in renewable energy sources $[3,12]$. In this regard, the incentive to invest in renewables, which involves the dedication of the farm to ecological crops [8], stands out. This incentive may be due to two reasons. First, the reluctance to use polluting fuels by farmers who adopt this productive approach. Also, as a tool for farm production diversification, given that ecological type crops have a higher risk of obtaining lower volume productions or even losing crops due to pests or adverse weather conditions [10]. In fact, Borchers et al. [19] calculate that, in the United States, in organic farms the probability of adopting renewable energy generation technologies is around five times higher than in conventional farms. Finally, we must take into account the biophysical characteristics of the farm as determinants of investment in renewable energy production, such as the amount of sunshine in the area, the average wind force, soil erosion, slope of the terrain or rainfall $[8,10]$.

Finally, literature analyzes a series of socioeconomic determinants for investment in renewable energy production, among which are accessibility to information flows and the level of income perceived by farmers. Regarding accessibility to information, some contributions suggest that farmers' access to information on available energy technologies may delay or accelerate their adoption $[10,16]$. In this regard, Beckman and Xiarchos, [8] and Borchers et al. [19] find, in the case of California and the United States, respectively, that there is a significant relationship between the adoption of renewable energy by farms and their Internet access. On the other hand, the income level of farmers seems to be a driver for investment in renewable energy generation $[8,19,21]$, even more so when and to the extent that these revenues have a different origin to the farm itself [12], which could be due to the need to have resources to finance such investment.

Additionally, it is worth highlighting the growing importance of a regional approach that encompasses a series of determinants closely linked to public policy measures that stimulate the adoption of renewable energy generation systems in farms. Thus, authors such as Schafffer and Düvelmeyer [10] distinguish between determinants associated with the individual characteristics of farms and farmers, and regional factors. This approach acquires even greater significance in the 
case of countries such as Spain, where there is a high degree of decentralization, as a result of which regional governments acquire a central role in energy policies [11]. The importance of this approach has been reflected in the different integrated national energy and climate plans of the countries of the European Union for the period 2021-2030. In fact, in the draft of the plan for Spain, there is an explicit mention of the fundamental role of regional administrations in the process of energy transition towards a sustainable model [6]. However, there are few studies on the adoption of energy-generating technologies from renewable sources that take into account the regional scope, usually focusing on the individual characteristics of different farms [19].

The drivers that make up this territorial dimension linked to regional public policies can be classified as general policies to support agricultural income and specific policies to encourage the deployment of renewable energies.

Agricultural income support policies, such as payments to farms derived from the Common Agricultural Policy, consist of ensuring income flows to farmers that help them have sufficient resources to consider incorporating systems of renewable energy production or the cultivation of bioenergy supply species, especially when a high initial investment is required [3].

Furthermore, within the incentive policies for the deployment of renewable energies in the agricultural sector, two types of measures can be distinguished.

The first type is made up of technology push measures, aimed at promoting R \& D activities to promote the development of technological learning curves in order to facilitate the incorporation of renewable energy sources to agricultural holdings, through direct investment or grants [13]. In the case of Spain, the Integrated National Climate Energy Plan already warns of the privileged position of regions when exploiting their strengths, increasing their competitiveness and their potential for innovation to contribute to the objectives set for 2030.

To do this, The Spanish Science and Technology and Innovation Strategy and State Plans for scientific and technical research and innovation define the national smart specialization framework (RIS3) that regions customize through their corresponding research and innovation strategies. Within this framework is the S3-Energy platform created by the European Commission, which connects and coordinates regional efforts in research, development and innovation in the fields of energy and climate [6].

The second type are made up of market pull measures, charged with stimulating the settlement of available energy production technologies through renewable sources on farms, mainly from subsidies and grants [13]. Among these measures applied by regional and local authorities, the most outstanding are those aimed at promoting self-consumption based on process simplification processes and the development of energy transport infrastructure in collaboration with the central administration, the enhancement of the production and use of biogas [16] and use of biomass [6].

From the above-mentioned determinants, and paying special attention to the influence that the regional context can exert, a multilevel logit model has been proposed in order to estimate the effect of each of them on the probability of a Spanish farm adopting a system of renewable energy production. In the following subsections, the principal methodological aspects are presented, and the model is specified. Then the main results obtained are shown in Section 3.

\subsection{Data}

The sample of farms on which the analysis has been carried out was extracted from the SSF-2016 prepared by the INE, in accordance with the harmonized criteria provided by the European Union. It is a statistical tool that allows information to be obtained about the changes experienced in Spanish agriculture and the structure of farms compared to other member countries of the European Union in the inter-census period.

The population under study in this survey are farms that have at least one hectare of agricultural land in use, along with those farms whose agricultural area in use is less than one hectare, if they produce a certain quantity for sale, or their Production unit exceeds certain physical thresholds. In total, 
this survey has enabled the collection of complete information corresponding to 56,051 farms located throughout the national territory.

In order to identify the farms that have some type of link with renewable energy sources, a section of the questionnaire asked precisely if the business had carried out, in a complementary way to the main activity, renewable energy production activities (wind, solar, biogas ...) to be sold. Only 128 farms answered affirmatively to this question, which were automatically incorporated into our sample. Figure 1 shows the regional distribution of these farms.

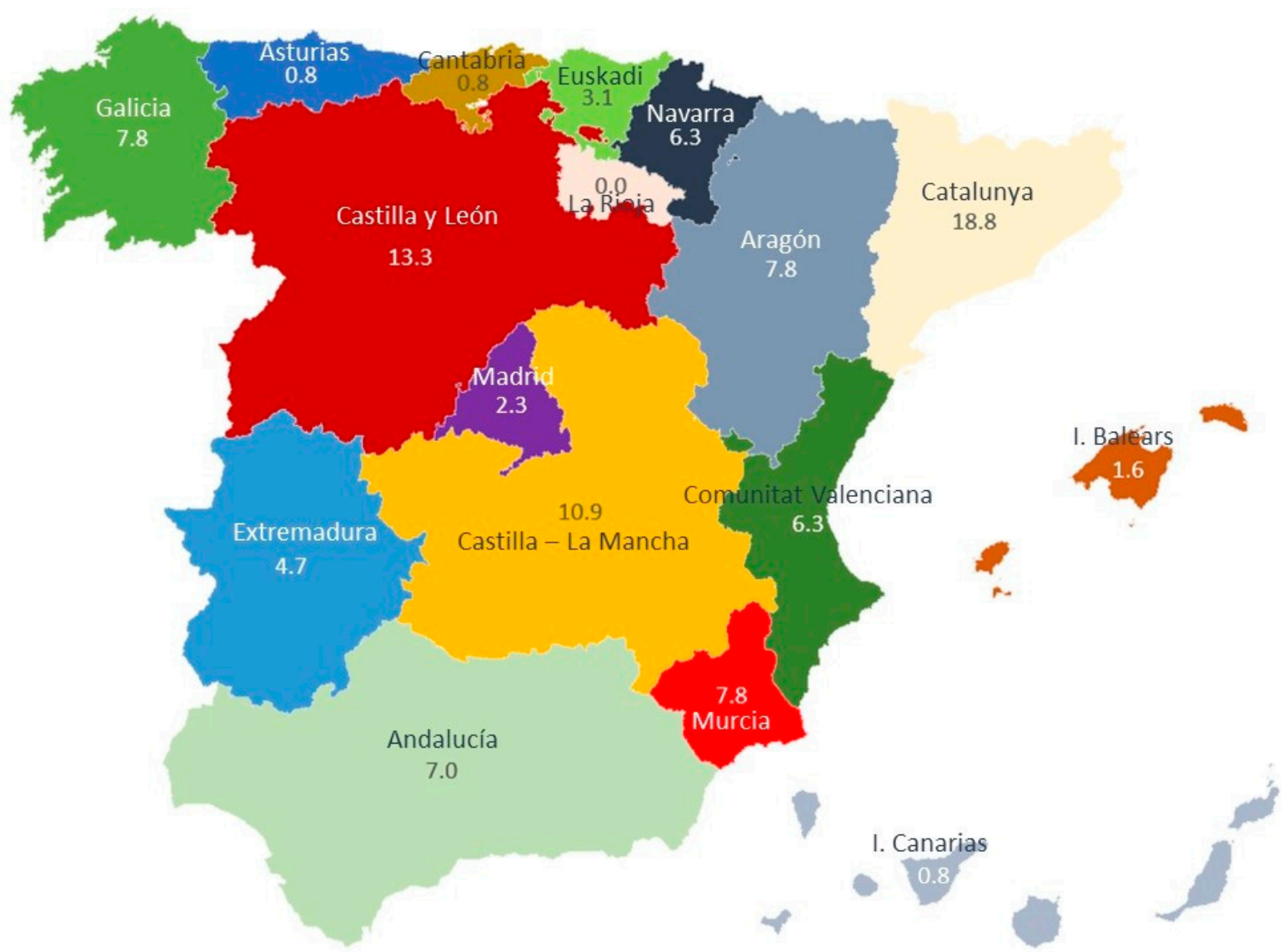

Figure 1. Distribution by regions of agricultural farms with renewable energy production (\%).

The next step was to randomly select a set of farms that, on the contrary, did not have that link with renewable energy production, trying to maintain a certain balance with respect to the number of farms that made up the opposite category. The only requirement imposed on this selection was the maintenance of a certain proportionality with the regional distribution of the total of the farms surveyed. So finally, our sample consists of 428 farms distributed throughout the Spanish territory.

\subsection{Variables}

The dependent variable in the proposed multilevel logit model reflects the probability of agricultural companies investing in renewable energy. This propensity has been represented by a dichotomous variable constructed from the question from the SSF-2016, where enquiries are made about the completion, on a complementary basis, of renewable energy production activities. So, this variable will adopt the value 1 if the company has declared to have carried out this type of activity, and 0 otherwise.

For their part, the explanatory variables correspond to factors that can condition the decision of farms to invest in renewable energy. In this work we expressly differentiate between the elements associated with the characteristics of the farm, including also in this group the attributes of the person who is in charge of its management, and those other aspects related to the features of the 
regional environment in which the farm is located. Table 3 shows the variables considered in the model specification.

Table 3. Explanatory variables specified in the multilevel logit model.

\begin{tabular}{|c|c|c|}
\hline Variable & Description & Source \\
\hline \multicolumn{3}{|c|}{ Farm-Level Determinants } \\
\hline SIZE & Work units in total years & SSF-2016. INE \\
\hline PROFES & $\begin{array}{l}\text { Dummy: Value } 1 \text { if the farm takes the status } \\
\text { of a trading company }\end{array}$ & SSF-2016. INE \\
\hline PERMANENT & $\begin{array}{l}\text { Percentage of fixed salary work units with } \\
\text { regard to total salaried workers }\end{array}$ & SSF-2016. INE \\
\hline PROPERTY & $\begin{array}{l}\text { Dummy: Value } 1 \text { if the holder farm owns } \\
50 \% \text { or more of the agricultural land in use }\end{array}$ & SSF-2016. INE \\
\hline $\mathrm{ECO}$ & $\begin{array}{l}\text { Dummy: Value } 1 \text { if the farm uses ecological } \\
\text { farming methods }\end{array}$ & SSF-2016. INE \\
\hline AGE & Age of the farm manager & SSF-2016. INE \\
\hline GENDER & Sex of the farm manager & SSF-2016. INE \\
\hline EDUCATION & $\begin{array}{l}\text { Dummy: Value } 1 \text { if the farm manager has } \\
\text { professional agricultural studies }\end{array}$ & SSF-2016. INE \\
\hline TRAINING & $\begin{array}{l}\text { Dummy: Value } 1 \text { if the farm manager has } \\
\text { received a training course over the last } 12 \\
\text { months }\end{array}$ & SSF-2016. INE \\
\hline \multicolumn{3}{|c|}{ Regional-Level Determinants } \\
\hline INCOME & $\begin{array}{l}\text { Value of regional agricultural income per } \\
\text { worker in agriculture }\end{array}$ & $\begin{array}{l}\text { Agriculture economic accounts. Ministry } \\
\text { for agriculture, fisheries and food }\end{array}$ \\
\hline ENERGY & $\begin{array}{l}\text { Weight of consumption of energy inputs in } \\
\text { agricultural production }\end{array}$ & $\begin{array}{l}\text { Regional electricity system indicators. } \\
\text { Spanish Electricity Network (REE) }\end{array}$ \\
\hline CAPACITY & $\begin{array}{l}\text { Weight of renewable energy in the total } \\
\text { power installed in the region }\end{array}$ & $\begin{array}{l}\text { Regional electricity system indicators. } \\
\text { Spanish Electricity Network (REE) }\end{array}$ \\
\hline R\&D & $\begin{array}{c}\text { Percentage of regional expenditure on R\&D } \\
\text { with regard to GDP }\end{array}$ & Statistics on R\&D activities. INE \\
\hline
\end{tabular}

Source: own elaboration.

The set of variables related to the characteristics of the farm firstly includes the size of the farm measured from the number of total work units (SIZE). Since agriculture is an activity that is severely affected by seasonality, and therefore, also to seasonal work, it is more appropriate to use this measure instead of the number of employees. Professionalism in management is another factor that can also condition the propensity of an agricultural exploitation to invest in renewable energy. In this work, this professionalized management has been collected from a dummy variable that adopts the value 1 if the legal status of the farm is that of a commercial company, and 0 otherwise (PROFES).

In addition, farms that enjoy greater stability in their business may also exhibit a greater tendency to embark on new projects and investment and diversify their activities. For this reason, the model includes a variable that measures the proportion that fixed salaried workers represent with respect to the total farm wage earners (PERMANENT) and a dummy variable that takes the value 1 if $50 \%$ or more of the agricultural area in use belongs to the farm owner, and 0 otherwise (PROPERTY). Furthermore, a dummy variable that adopts the value 1 has been included, if the farm uses organic farming methods, and 0 otherwise (ECO), with the logic that this circumstance may reflect the commitment of farm management to the environmental sustainability issue. 
With regard to specific features of the head of the holding, two variables that measure basic features such as age (AGE) and gender (GENDER) have been included in the first place. In addition, two other variables that aim to analyze the influence of training have been incorporated. The first one is a dummy variable that adopts value 1 if the farm manager has agricultural university studies, and 0 otherwise (EDUCATION). The second is related to the strategies of continuous training and knowledge update, and is built again as a dichotomous variable that takes value 1 if the head of the operation has received a training course over the last 12 months (TRAINING).

On the other hand, as previously mentioned, the regional environment can condition the predisposition of the farm towards investment in renewable energy, depending upon certain factors. One of these factors is the situation and structure of the regional agricultural activity itself. For this reason, a variable that represents the value of regional agricultural income per employee in agriculture has been included to reflect the profitability of agriculture in the region (INCOME), and a variable that reflects the intensity of energy consumption with respect to agricultural production, to analyze the effect that dependence on energy resources can have on the tendency to invest in renewable energy (ENERGY).

Both variables were constructed with information extracted from the Economic Agricultural Accounts published by the Ministry of Agriculture, Fisheries and Food. From another perspective, action developed by regional governments is also an important factor capable of promoting or, on the contrary, discouraging investment by agricultural holdings. To analyze this possible influence, the weight of renewable energy in the total installed power in the region has been included (CAPACITY) as a proxy for the facility granted by the regional government for the execution of this type of initiatives. This variable has been prepared based on regional statistics for the national electricity grid provided by the Red Eléctrica de España company. Finally, a variable that represents the percentage of regional expenditure on R \& D with respect to GDP has been included, calculated from information published by the National Institute of Statistics of Spain (INE).

Due to technical and economic implications, it is foreseeable that the influence of these regional characteristics on the decision of agricultural holdings to invest in renewable energy is not immediate, but requires one or two years for its realization. For this reason, and to avoid potential endogeneity problems in any regional variables, these have been incorporated into the model with a time delay of two years. Therefore, the variables that include the characteristics of the farm refer to the year 2016, while regional variables adopt 2014 values.

Descriptive statistics of the explanatory variables are shown in Table 4.

Table 4. Descriptive statistics.

\begin{tabular}{cccccc}
\hline Variable & Mean & Standard Deviation & Min & Max & Sample Size \\
\hline SIZE & 2814.35 & 7088.17 & 4 & 70,525 & 428 \\
\hline PROFES & 0.16 & 0.37 & 0 & 1 & 428 \\
\hline PERMANENT & 42.03 & 47.44 & 0 & 100 & 428 \\
\hline PROPERTY & 0.60 & 0.49 & 0 & 1 & 428 \\
\hline ECO & 0.05 & 0.22 & 0 & 1 & 428 \\
\hline AGE & 53.73 & 11.89 & 25 & 90 & 428 \\
\hline GENDER & 0.81 & 0.40 & 0 & 1 & 428 \\
\hline EDUCATION & 0.10 & 0.29 & 0 & 1 & 428 \\
\hline TRAINING & 0.21 & 0.40 & 0 & 1 & 428 \\
\hline
\end{tabular}


Table 4. Cont.

\begin{tabular}{cccccc}
\hline Variable & Mean & Standard Deviation & Min & Max & Sample Size \\
\hline \multicolumn{7}{c}{ Regional-Level } \\
\hline INCOME & $31,628.54$ & $13,034.11$ & 6749.52 & $59,059.3$ & 17 \\
\hline ENERGY & 11.64 & 11.25 & 4.69742 & 62.7047 & 17 \\
\hline CAPACITY & 44.42 & 20.44 & 3.65936 & 74.1611 & 17 \\
\hline R\&D & 1.03 & 0.41 & 0.32 & 2.04 & 17 \\
\hline \multicolumn{7}{c}{ Source: own elaboration. }
\end{tabular}

\subsection{Model Specification}

The sample used in this paper has a hierarchical structure, with data from farms (first level) grouped into regions (second level), and the proposed empirical model includes explanatory variables corresponding to each of these two levels. This hierarchical structure has a series of implications to be considered.

In particular, the considerable margin of political decision attributed in practice to the Autonomous Communities in different fields, added to the particularities associated, among other aspects, to the orographic and climatological characteristics of each, presumably means that the behavior of the farms in the same region with respect to renewable energies, is influenced by common factors that give more homogeneity to their respective decisions than those taken by farms located in a different region.

From an econometric point of view, this structure violates the independence of the observations required by traditional regression models, resulting in biased estimators of standard errors being obtained, and increasing the probability of committing Type I errors [23].

To this we must add the risk of incurring the fallacy of the wrong level that derives from analyzing the data at a given level and formulating the conclusions at a different level [24].

Multilevel analysis allows these problems to be overcome by explicitly recognizing the possibility that individuals belonging to the same group have a greater similarity with each other than with individuals belonging to a different group [25]. These sort of hierarchical models are also called mixed-effect models, since there is a combination of fixed effects and random effects (see $[26,27])$.

The dependent variable in our analysis is binary, adopting the value 1 if the farm produces in its facilities some type of renewable energy, and 0 otherwise. For this reason, the model to be estimated takes the form of a multilevel logit model with the following structure:

$$
\operatorname{logit}\left\{\operatorname{Pr}\left(y_{i j}=1 \mid X_{i j}\right)\right\}=\beta_{0 j}+\sum_{1}^{p} \beta_{p} X_{p i j}
$$

where the probability that a farm located in region $\mathrm{j}$ develops activities related to the production of renewable energy is made dependent on set $(X)$ of explanatory variables, which represent the characteristics of the farm itself. At the regional level, the group of co-variables $(Z)$ is used to explain the variation of the independent term $\beta_{0 j}$ with the random parameter $\mu_{j}$ :

$$
\beta_{0 j}=\gamma_{00}+\sum_{1}^{q} \gamma_{q 0} Z_{q j}+\mu_{j}
$$

Combining both equations, we obtain a mixed effects model in which the random part, which in this case affects only the independent term, is represented by $\mu_{j}$, which is distributed according to a multivariate normal of mean 0 and variance $\psi$, and which also verifies the quality of independence between regions [26]: 


$$
\operatorname{logit}\left\{\operatorname{Pr}\left(y_{i j}=1 \mid X_{i j}, \mu_{j}\right)\right\}=\gamma_{00}+\sum_{1}^{q} \gamma_{q 0} Z_{q j}+\sum_{1}^{p} \beta_{p} X_{p i j}+\mu_{j}
$$

\section{Results}

One of the requirements for applying the multilevel analysis technique is that the between-groups variance of the dependent variable is significant. To verify this, a variance decomposition model will be used with a single factor coinciding with the grouping variable, in this case the region, in which explanatory variables are not included. Due to its basic character, this model is known in the literature as null model or empty model. The first column of Table 5 shows the results of the estimation of this model.

Table 5. Alternative estimates of the logit model.

\begin{tabular}{|c|c|c|c|c|}
\hline & Empty Model & Model 1 & Model 2 & Model 3 \\
\hline Intercept & $\begin{array}{c}-0.996^{* * *} \\
(0.184)\end{array}$ & $\begin{array}{c}-1.999 * * * \\
(0.708)\end{array}$ & $\begin{array}{c}-2.916^{* * * *} \\
(1.171)\end{array}$ & $\begin{array}{c}-3.699 * * * \\
(0.987)\end{array}$ \\
\hline \multicolumn{5}{|l|}{ Fixed effects } \\
\hline \multicolumn{5}{|l|}{ Farm-level } \\
\hline SIZE & & $\begin{array}{l}0.535^{*} \\
(0.000)\end{array}$ & $\begin{array}{l}0.484^{*} \\
(0.000)\end{array}$ & $\begin{array}{l}0.506^{*} \\
(0.000)\end{array}$ \\
\hline PROFES & & $\begin{array}{c}0.837^{* * *} \\
(0.350)\end{array}$ & $\begin{array}{c}0.861^{* * *} \\
(0.348)\end{array}$ & $\begin{array}{c}0.841^{* * *} \\
(0.348)\end{array}$ \\
\hline PERMANENT & & $\begin{array}{c}1.217^{* * * *} \\
(0.003)\end{array}$ & $\begin{array}{c}1.245^{* * *} \\
(0.003)\end{array}$ & $\begin{array}{c}1.248^{* * *} \\
(0.003)\end{array}$ \\
\hline PROPERTY & & $\begin{array}{c}0.324 \\
(0.256)\end{array}$ & $\begin{array}{c}0.317 \\
(0.255)\end{array}$ & $\begin{array}{c}0.320 \\
(0.255)\end{array}$ \\
\hline ECO & & $\begin{array}{c}0.278 \\
(0.548)\end{array}$ & $\begin{array}{c}0.309 \\
(0.550)\end{array}$ & $\begin{array}{c}0.289 \\
(0.547)\end{array}$ \\
\hline AGE & & $\begin{array}{l}-0.194 \\
(0.011)\end{array}$ & $\begin{array}{l}-0.216 \\
(0.011)\end{array}$ & $\begin{array}{l}-0.212 \\
(0.011)\end{array}$ \\
\hline GENDER & & $\begin{array}{c}0.198 \\
(0.338)\end{array}$ & $\begin{array}{c}0.277 \\
(0.341)\end{array}$ & $\begin{array}{c}0.232 \\
(0.335)\end{array}$ \\
\hline EDUCATION & & $\begin{array}{l}0.513^{*} \\
(0.408)\end{array}$ & $\begin{array}{l}0.484^{*} \\
(0.410)\end{array}$ & $\begin{array}{l}0.463 * \\
(0.409)\end{array}$ \\
\hline TRAINING & & $\begin{array}{c}0.238 \\
(0.306)\end{array}$ & $\begin{array}{c}0.185 \\
(0.305)\end{array}$ & $\begin{array}{c}0.197 \\
(0.305)\end{array}$ \\
\hline \multicolumn{5}{|l|}{ Regional-level } \\
\hline INCOME & & & $\begin{array}{l}-0.012 \\
(0.000)\end{array}$ & \\
\hline ENERGY & & & $\begin{array}{l}-3.036 \\
(0.098)\end{array}$ & \\
\hline CAPACITY & & & $\begin{array}{c}0.640 \\
(0.010)\end{array}$ & $\begin{array}{l}0.689 * \\
(0.009)\end{array}$ \\
\hline$R \& D$ & & & $\begin{array}{l}0.776^{* *} \\
(0.429)\end{array}$ & $\begin{array}{l}0.913^{* *} \\
(0.426)\end{array}$ \\
\hline \multicolumn{5}{|l|}{ Random effects } \\
\hline$\sigma_{\mu}^{2} \mu$ & $\begin{array}{c}0.259 \\
(0.186)\end{array}$ & $\begin{array}{c}0.412 \\
(0.251)\end{array}$ & $\begin{array}{c}0.186 \\
(0.137)\end{array}$ & $\begin{array}{c}0.222 \\
(0.162)\end{array}$ \\
\hline LR test & $7.56^{* * *}$ & $12.81 * * *$ & $4.17^{* *}$ & $6.02 * * *$ \\
\hline AIC & & 457.45 & 457.15 & 454.83 \\
\hline Pseudo $\mathrm{R}^{2}$ (McFadden) & & 0.154 & 0.170 & 0.167 \\
\hline Pseudo $\mathrm{R}^{2}$ (Snijders and Bosker) & & 0.234 & 0.291 & 0.279 \\
\hline
\end{tabular}

Source: own elaboration. Notes: ${ }^{*}=p \leq 10 \%{ }^{* *}=p \leq 5 \%{ }^{* * *}=p \leq 1 \%$. Standard errors in parentheses. 
The inter-region variance is estimated at 0.26 with a standard error of 0.19 . The likelihood ratio test has a value of 7.56 with an associated p-value of less than 0.01 . This result confirms the existence of a non-zero inter-region variance, and therefore, justifies the application of the multilevel analysis technique [27]. From these values it is possible to calculate the intra-class correlation (ICC) as a representative measure of the variation percentage of the dependent variable which is attributable to differences between the regions.

In this case, it is observed that most of the variation in the dependent variable has its origin in the differences between farms, while $7.3 \%$ of this said variance, based on the CCI value, can be attributed to differences in regional factors.

Although it may seem like an influence of reduced magnitude, it is a logical value, since the intra-class correlation tends to be smaller the larger the theoretical dimension of the group, its value oscillating between 0.05 and $0.85 \%$, for example, when the group identifies with the region [28-30].

Regarding the selection of explanatory variables, we follow a stepwise strategy. Thus, in the first model (Model 1) only variables at the farm level are entered, so that it is possible to establish comparisons with previous studies. Then, in a second estimate, the model is expanded to incorporate the regional level variables (Model 2). The inclusion of the regional characteristics results in a slight improvement of the Akaike Information Criterion (AIC) (from a value of 457.45 to a value of 457.15), while the goodness of fit measures considered (pseudo-R2) exhibit an appreciable increase. In Model 3, we intend to isolate the effect of the contextual variables related to the action of regional authorities (CAPACITY and R\&D). As shown in Table 5, this most parsimonious model gives rise to an improvement of the Akaike Information Criterion (AIC), as compared to Model 2.

As for explanatory variables pertaining to the farm dimension, the results point to four statistically significant variables. Three of them, PROFES, PERMANENT and SIZE, which have a relevant and positive effect on the probability that the farm will invest in renewable energies, refer to the characteristics of the farm, while the fourth, EDUCATION, corresponds to a characteristic of the person in charge. With regard to, firstly, the characteristics of the farm, as expected, the dimension (SIZE) is an element that determines the willingness to invest in renewable energy. It is well known that business size is an indicator that serves as a proxy for the set of financial and human resources of a company. In this sense, it is logical that the larger the farm size, the greater the probability of embarking on new projects other than the main activity. This result, together with the positive effect of the PROFES and PERMANENT variables that represent, respectively, their legal status and workforce stability, demonstrate that management professionalization and the solidity of the farm are elements that work in favor of investment in a renewable infrastructure. This could be in line with the opinion of authors who believe that this type of investment is favored by the farm's orientation towards obtaining an economic profit, which would be achieved through a strategy of production diversification $[14,18,21]$. On the other hand, other variables referring to the farm characteristics do not have statistically significant coefficients. Thus, PROPERTY, which includes the fact that most of the surface of the farm is owned by the person in charge, has a positive parameter associated, consistent with literature, which points to the fact that the ownership of the farm favors investment in renewables [8,14]; although in this case this relationship is not statistically significant. The same applies to ECO, which indicates whether the holding is dedicated to organic farming, which in the opinion of several authors favors investment in renewables $[8,10]$. The positive sign of the coefficient is consistent with this opinion, although the estimated relationship is not statistically significant.

As has been pointed out, the fourth variable at the farm level whose coefficient is statistically significant is EDUCATION, which refers to the person in charge of the farm as having studied agriculture at a university. The positive coefficient is in line with the authors who emphasize the role of academic training as an important driver of investment in renewables $[12,14,17,21]$. On the other hand, other variables referring to the characterization of the person in charge of the farm, such as age (AGE) or continuous training (TRAINING), although they have coefficients with the expected signs according to literature (negative and positive, respectively), are not statistically significant. The same 
applies to the GENDER variable, which includes the sex of the person in charge of the farm and which, in the light of the statistical significance of its associated coefficient, does not seem to have a significant influence on the probability that the farm will incorporate renewable infrastructures.

Turning to the variables belonging to the regional dimension, of the four specified variables, there are two whose coefficients are not statistically significant. The first is INCOME, which includes agricultural income for the region, which would be in apparent contradiction with the opinion of some authors who believe that the level of income of farmers is a relevant driver when investing in the generation of renewable energy, due to the cost of the said investment $[8,19,21]$; although these authors contemplate this income variable from the individual, instead of the regional dimension.

The second variable whose estimated coefficient is not significant is ENERGY, which refers to the intensity of the energy use of the regional agricultural sector. Therefore, apparently, there is no relationship between the intensity of energy consumption by farms and investment in renewable energy generation projects.

The suppression of the two previous variables in the third specification of the model increases the significance of another variable of regional dimension, CAPACITY, which includes the weight of renewable capacity installed in the region in relation to all of the total installed capacity. In addition, the coefficient is positive, which suggests that, in a regional context that favors investment in renewable capacity, the agricultural sector responds positively by increasing the probability of farms investing in this type of energy. In other words, the agricultural sector seems to respond positively to regional policies to support the diffusion of renewables. In this sense, this variable could be considered as a proxy for regional policies for the promotion of renewables, i.e., of the market-pull type. These policies highlight the elimination of administrative barriers (Reise et al. [16] emphasize the importance of these barriers), or the conditions derived from the energy transport infrastructure, mainly the infrastructure for farms to connect to the power grid [19].

Finally, the regional variable with a clearer statistical significance is $R \& D$, which includes the regional investment in $\mathrm{R} \& \mathrm{D}$ in relation to regional gross domestic product. In addition, the sign of the coefficient is positive, which implies that a greater relative investment in $\mathrm{R} \& \mathrm{D}$ encourages investment in renewable infrastructure by farms, in line with that suggested by authors such as Adams et al. [13]. It should be remembered that energy generation technologies from renewable sources are, in general, technologies developed relatively recently, and that many of them are still in the early stages of their development, so Research \& Development programs that enable an adaptation of these technologies to the farm environment are essential. In this sense, regional policies to support R \& D actions, i.e., technology-push policies, are essential in order for technologies to mature to a sufficient extent, so that farmers can decide to incorporate them into their holdings. This is what Schaffer \& Düvelmeyer [10] call "transformation ability", which is the ability of regions to adopt innovations and adapt them to their own context.

Once the results obtained were commented upon, the main conclusions of the study were summarized in the following section.

\section{Discussion and Concluding Remarks.}

Numerous authors have studied the drivers of and barriers to farm investment in renewable energy production technologies, often focusing on some specific technology or type of energy. In this paper, a global assessment of these factors is made, for most of the renewable technologies incorporated by farms, in line with works such as Tate et al. [17], Schafffer and Düvelmeyer [10], Sutherland et al. [21] and Ge et al. [9], for Spain, which is one of the main European agricultural powers. In addition, and unlike most of the preceding studies, the analysis includes variables at two levels of aggregation: At the farm level (individual), and at the regional level. This is because the regional dimension, especially in very decentralized countries such as Spain, takes a fundamental role at social, economic and political levels, as evidenced by the continuous references to this administrative level in the recent Integrated National Energy and Climate Plan of Spain [6]. Ultimately, in this work we start with the hypothesis 
that the regional context in which the farm is located can condition its entire activity, including, particularly what we are interested in here, which is its predisposition to invest in renewable energies.

To assess the relevance of the various determinants, both individually and regionally, on the decision of the farms to incorporate energy generation through renewable technologies into their activity, a discrete multilevel logit choice model has been estimated, in which the dependent variable is interpreted as the probability that a farm will invest in renewable energy.

Among the significant determinants at the farm level, those that imply a professionalization of farms (size of the farm, commercial legal form, structure of the stable wage labor), and university training of the person in charge of the farm, stand out. These results are consistent with the literature on the previous topic.

On the other hand, insufficient statistical evidence has been found to confirm the significant influence of other determinants present in literature, such as the ownership of the farm or the age of the person in charge.

With regard to the determinants at the regional level, the results highlight the importance of the $R \& D$ investment carried out in the region, as well as the fact that there is an environment that favors the diffusion of renewable energies in the region. Other variables, such as the level of agricultural income or regional energy intensity, do not seem to have significant relevance in the light of the results.

Given the comments above, it seems clear that the role of the regional administration is essential when it comes to encouraging the incorporation of renewable energy generation technologies in agricultural holdings.

Thus, the relevance of $R \& D$ investment leads us to consider the need for the regional administration through its technology-push policies and through its network of public research organizations, and the budgetary provision of programs to support Research and Development for renewable energy production systems in the agricultural field. The objective with this $\mathrm{R} \& \mathrm{D}$ investment is to achieve "transformation capability" [10], so that the investment that farmers perceive that they have to make to install the infrastructure, and the risk associated with the investment, can be reduced.

Furthermore, it is essential for regional administrations additionally to make an effort in market-pull policies, i.e., aimed at facilitating the diffusion of renewable energy production technologies in the territory. The results obtained in this work corroborate this: There is an effect of technological permeability between farms and their environment, so that if there is an expansion of renewable technologies in the environment, these technologies will eventually be introduced in farms. This is so, among other reasons, due to the very nature of market-pull policies applied by regional governments, and which can go beyond the subsidy or direct funding of renewable technology. Thus, for example, Reise et al. state that policies should be established to eliminate administrative barriers, i.e., to facilitate investment by establishing a climate in which administrative procedures are simple and with relatively short lead times. Another public policy of this type that regional administrations can undertake is to boost the construction of the necessary public infrastructure, so that investors in renewables (and among them, farmers) can obtain an optimal return on their investment. This type of investment includes improvements in the infrastructure for farms to connect to the electricity grid, or in communication channels to transport bioenergy products.

Author Contributions: Conceptualization, M.J.R.-F., M.-J.G.-P. and M.-Á.T.; Methodology, M.J.R.-F., M.-J.G.-P. and M.-Á.T.; Software, M.J.R.-F., M.-J.G.-P. and M.-Á.T.; Validation, M.J.R.-F., M.-J.G.-P. and M.-Á.T.; Formal Analysis, M.J.R.-F., M.-J.G.-P. and M.-Á.T.; Investigation, M.J.R.-F., M.-J.G.-P. and M.-Á.T.; Resources, M.J.R.-F., M.-J.G.-P. and M.-Á.T.; Data Curation, M.J.R.-F., M.-J.G.-P. and M.-Á.T.; Writing-Original Draft Preparation, M.J.R.-F., M.-J.G.-P. and M.-Á.T.; Writing-Review \& Editing, M.J.R.-F., M.-J.G.-P. and M.-Á.T.; Visualization, M.J.R.-F., M.-J.G.-P. and M.-Á.T.; Supervision, M.J.R.-F., M.-J.G.-P. and M.-Á.T.; Project Administration, M.J.R.-F., M.-J.G.-P. and M.-Á.T.; Funding Acquisition, M.J.R.-F., M.-J.G.-P. and M.-Á.T.

Funding: This research was funded by the Faculty of Law and Social Sciences, University of Castilla-La Mancha grant number [0002-2019] And The APC was funded by the Faculty of Law and Social Sciences, University of Castilla-La Mancha. 
Acknowledgments: We thank three anonymous reviewers for their valuable comments which have contributed to the improvement of this paper.

Conflicts of Interest: The authors declare no conflict of interest.

\section{References}

1. UNFCCC, United Nations Framework Convention on Climate Change. Paris Agreement; United Nations: Paris, France, 2015.

2. Pedroli, B.; Langeveld, H. Impacts of Renewable Energy on European Farmers: Final Report; Directorate-General Agriculture and Rural Development, European Commission: Brussels, Belgium, 2011.

3. Bartolini, F.; Viaggi, D. An analysis of policy scenario effects on the adoption of energy production on the farm: A case study in Emilia-Romagna (Italy). Energy Policy 2012, 51, 454-464. [CrossRef]

4. Bardi, U.; El Asmar, T.; Lavacchi, A. Turning electricity into food: The role of renewable energy in the future of agriculture. J. Clean. Prod. 2013, 53, 224-231. [CrossRef]

5. Sutherland, L.-A.; Peter, S.; Zagata, L. Conceptualising multi-regime interactions: The role of the agriculture sector in renewable energy transitions. Res. Policy 2015, 44, 1543-1554. [CrossRef]

6. Ministry for the Ecological Transition. Plan Nacional Integrado de Energía y Clima; Spanish Government: Madrid, Spain, 2019.

7. EIP-AGRI, Agricultural European Innovation Partnership. Enhancing Production and Use of Renewable Energy on the Farm; European Commission: Brussels, Belgium, 2018.

8. Beckman, J.; Xiarchos, I.M. Why are Californian farmers adopting more (and larger) renewable energy operations? Renew. Energy 2013, 55, 322-330. [CrossRef]

9. Ge, J.; Sutherland, L.-A.; Polhill, J.G.; Matthews, K.; Miller, D.; Wardell-Johnson, D. Exploring factors affecting on-farm renewable energy adoption in Scotland using large-scale microdata. Energy Policy 2017, 107, 548-560. [CrossRef]

10. Schaffer, A.; Düvelmeyer, C. Regional drivers of on-farm energy production in Bavaria. Energy Policy 2016, 95, 361-369. [CrossRef]

11. Ruiz-Fuensanta, M.J. The region matters: A comparative analysis of regional energy efficiency in Spain. Energy 2016, 101, 325-331. [CrossRef]

12. Jensen, K.; Clark, C.; Ellis, P.; English, B.; Menard, J.; Walsh, M.; de la Torre-Ugarte, D. Farmer willingness to grow switchgrass for energy production. Biomass Bioenergy 2007, 31, 773-781. [CrossRef]

13. Adams, P.; Hammond, G.; Mcmanus, M.; Mezzullo, W.G. Barriers to and drivers for UK bioenergy development. Renew. Sustain. Energy Rev. 2011, 15, 1217-1227. [CrossRef]

14. Tranter, R.B.; Swinbank, A.; Jones, P.J.; Banks, C.J.; Salter, A.M. Assessing the potential for the uptake of on-farm anaerobic digestion for energy production in England. Energy Policy 2011, 39, 2424-2430. [CrossRef]

15. Huttunen, S. Wood energy production, sustainable farming livelihood and multifunctionality in Finland. J. Rural Stud. 2012, 28, 549-558. [CrossRef]

16. Reise, C.; Musshoff, R.; Granoszewski, K.; Spiller, A. Which factors influence the expansion of bioenergy? An empirical study of the investment behaviours of German farmers. Ecol. Econ. 2012, 73, $133-141$. [CrossRef]

17. Tate, G.; Mbzibain, A.; Ali, S. A comparison of the drivers influencing farmers' adoption of enterprises associated with renewable energy. Energy Policy 2012, 49, 400-409. [CrossRef]

18. Brudermann, T.; Reinsberger, K.; Orthofer, A.; Kislinger, M.; Posch, A. Photovoltaics in agriculture: A case study on decision making of farmers. Energy Policy 2013, 61, 96-103. [CrossRef]

19. Borchers, A.M.; Xiarchos, I.; Beckman, J. Determinants of wind and solar energy system adoption by U.S. farms: A multilevel modeling approach. Energy Policy 2014, 69, 106-115. [CrossRef]

20. Sutherland, L.-A.; Holstead, K.L. Future-proofing the farm: On-farm wind turbine development in farm business decision-making. Land Use Policy 2014, 36, 102-112. [CrossRef]

21. Sutherland, L.A.; Toma, L.; Barnes, A.P.; Matthews, K.B.; Hopkins, J. Agri-environmental diversification: Linking environmental, forestry and renewable energy engagement on Scottish farms. J. Rural Stud. 2016, 47, 10-20. [CrossRef]

22. Del Río, P.; Burguillo, M. Assessing the impact of renewable energy deployment on local sustainability: Towards a theoretical framework. Renew. Sustain. Energy Rev. 2008, 12, 1325-1344. [CrossRef] 
23. Kidwell, R.; Mossholder, K.; Bennett, N. Cohesiveness and Organizational Citizenship Behavior: A Multilevel Analysis Using Work Groups and Individuals. J. Manag. 1997, 23, 775-793. [CrossRef]

24. Klein, K.J.; Dansereau, F.; Hall, R.J. Levels Issues in Theory Development, Data Collection, and Analysis. Acad. Manag. Rev. 1994, 19, 195-229. [CrossRef]

25. Lee, B.H. Using hierarchical linear modeling to illustrate industry and group effects on organizational commitment in a sales context. J. Manag. Issues 2003, 15, 353-368.

26. Snijders, T.A.B.; Bosker, R.J. Multilevel Analysis: An Introduction to Basic and Advanced Multilevel Modelling; Sage Publications: London, UK, 2012.

27. Rabe-Hesketh, S.; Skrondal, A. Multilevel and Longitudinal Modeling Using Stata; STATA Press: College Station, Texas, USA, 2008.

28. Colin, A.; Trivedi, P.K. Microeconometrics: Methods and Applications; Cambridge University Press: New York, NY, USA, 2005.

29. Gulliford, M.C.; Ukoumunne, O.C.; Chinn, S. Components of variance and intraclass correlations for the design of community-based surveys and intervention studies: Data from the Health Survey for England 1994. Am. J. Epidemiol. 1999, 149, 876-883. [CrossRef] [PubMed]

30. Hedeker, D.; Gibbons, R.D.; Flay, B.R. Random-effects regression models for clustered data: With an example from smoking prevention research. J. Consult. Clin. Psychol. 1994, 62, 757-765. [CrossRef] [PubMed]

(C) 2019 by the authors. Licensee MDPI, Basel, Switzerland. This article is an open access article distributed under the terms and conditions of the Creative Commons Attribution (CC BY) license (http://creativecommons.org/licenses/by/4.0/). 